\title{
Water Values: Participatory Water Ecosystem Services Assessment in the Arno River Basin, Italy
}

\author{
T. Pacetti ${ }^{1}$ (D) $\cdot$ G. Castelli ${ }^{2} \cdot$ E. Bresci ${ }^{2} \cdot$ E. Caporali ${ }^{1}$
}

Received: 20 February 2020 / Accepted: 22 September 2020 /

Published online: 12 October 2020

(C) The Author(s) 2020

\begin{abstract}
Water-related Ecosystem Services (WES), namely the multiple benefits that humans can obtain from water or water-related functions of an ecosystem, constitute a useful perspective to look at the overlap between biosphere and anthroposphere and to explore their sustainable coupling. On one hand, society acts as a driver of landscapes transformation, influencing the ecohydrological processes that underpin a large set of potential WES. On the other hand, society is the recipient of the WES provided by ecosystems, determining the actual production of services. Aiming at exploring the ecosystem-water-society nexus, this study develops a 4-tiered methodology for the participatory evaluation of WES as a basis to facilitate a shared watershed planning process in the Arno river basin (Central Italy), carried out within the framework of the Tuscany Regional Law for participation. Starting from the biophysical assessment of the study area and the analysis of the population, multiple focus groups were organized to allow the participatory evaluation of WES, mainly targeting low impact stakeholders. The proposed approach allowed the WES mapping and the identification of valuable WES characterised by a critical status. These results served as the basis for the analysis of multiple scenarios and the codefinition of a shared management strategy, jointly with decision makers. The analysis highlights the potential of WES concept as a suitable common language for developing participatory processes that support integrated water resources management. The proposed participatory WES assessment approach can sustain the active involvement of all interested parties in Water Framework Directive implementation (Art.14) and foster a wider policy objective of sustainability through the management plans.
\end{abstract}

Keywords Ecosystem services · Participatory approach $\cdot$ Water resources management $\cdot$ Low priority stakeholders $\cdot$ River basin management

T. Pacetti

tommaso.pacetti@unifi.it

Extended author information available on the last page of the article 


\section{Introduction}

Water is the determinant of multiple processes that link terrestrial and aquatic ecosystems, defining habitats and their productivity (Falkenmark 2003; Coates et al. 2013). Ecosystem Services (ES), namely the conditions and processes through which ecosystems sustain and fulfill human life (MEA 2005a, b), represent a useful perspective to explore the role of water in the ecosystems. Water-related Ecosystem Services (WES) are, specifically, the multiple benefits produced by the interactions between terrestrial ecosystems and freshwater as it moves through the landscape (Duku et al. 2015). Brauman et al. (2007), categorized WES into four classes according to the MEA classification ((MEA 2005a): supporting WES such as the support of vital estuaries and other habitats; provisioning WES that include water supply for the different sectors; regulating WES such as flow and sediment regulation; cultural WES that are related to the provision of religious, educational and tourist values. While Brauman et al. (2007) linked the WES definition to the underpinning hydrological process, WES can be also identified according to the ecosystem typology (e.g. rivers, lakes, wetlands) as described by Maes et al. (2016). Recently, Grizzetti et al. (2016) proposed a simplified classification of WES based on the Common International Classification of Ecosystem Services Version 4.3 (CICES 2015) and TEEB classification (TEEB 2010).

WES concept is a suitable tool to analyze the complex overlap of the biosphere, the hydrosphere and the anthroposphere; every ecohydrological process can provide a wide range of potential WES but it is the presence of recipients (i.e. society needs) that determine the conversion of an ecohydrological function into WES (Spangenberg et al. 2014). Therefore, it is extremely important to analyze human perceptions of the surrounding environment both to highlight the extents to which society is aware of the utilized WES and their value and to inform decision makers about the multiple WES to be managed in the territory. A better understanding of the different values that water can have within a catchment can lead to a more sustainable planning of socio-ecological catchment systems, interpreting ecosystems as a source of multiple benefits (i.e. WES) instead of being a development constrain (Everard et al. 2009).

Therefore, involvement of stakeholders becomes fundamental to explore the multiple WES provided by the ecosystems and to provide management solutions that bridge ecosystem functions with human needs. This aspect is also recognized as key element in the article 14 of the Water Framework Directive (WFD 2000) that supports public participation in river basin management planning. According to the Directive, information supply and consultation should be ensured during the production, review and updating of the river basin management plans. Although the active involvement of stakeholders is not specified, the WFD encourages the contribution of all interested parties in the planning process by discussing issues and contributing to their solution (EU 2003).

Since the release of the WFD, several experiences of public participation have been developed at various scales (i.e. international, national, regional and local) and using different participatory methods for water resources planning (Cernesson et al. 2005; Kallis et al. 2006). This helped to identify the specific requirements in terms of participation and decision-making processes design within the WFD implementation (Mostert et al. 2009, Fig. 1).

Focusing on the acceptance and the integration of different perspectives, the importance of developing a shared language that can facilitate a mutual learning appears clear. Indeed, the governance of complex socio-ecological systems (e.g. a watershed) requires dealing with different aspects of co-management in combination with learning-based approaches (Berkes 


\section{Role of stakeholder involvement}

Often, the means, timing and purpose of stakeholder involvement are not clarified. Moreover, the status of the initiative in which the stakeholders can become involved often remains unclear and the organizers sometimes lack decision-making powers. As a result, stakeholders may become frustrated or decide not to participate at all.

\section{Politics and institution}

Authorities must be willing and capable to start and manage participatory approaches. In practice, authorities often lack experience and may fear to lose control if they open up decision-making.

\section{Opportunities for interaction}

In practice, "participation" is often limited to information provision or obtaining views from the public by means of surveys, interviews, public commenting periods and public hearings. However, these means do not allow people to interact, discuss or develop something together. This is essential for improving legitimacy and extending "ownership" of decisions and for empowering citizens and promoting active citizenship

\section{Motivation and skills of leaders and facilitator}

Expert facilitation by persons that are seen as neutral can improve the legitimacy and efficacy of the participatory process. In practice, it is often a staff member from one of the interested parties that act as facilitator.

\section{Openness and trasparency}

Other factors promoting legitimacy and efficacy of participatory processes are open-ness and transparency. Openness and transparency can be promoted by joint devel-opment (or at least discussion) of the participatory process, by clear ground rules and by timely and continuous feedback, e.g. dissemination of minutes.

\section{Representativeness}

A stakeholder analysis at the beginning of the process can help organizers to target the most important stakeholders and understand what they need to participate.

\section{Acceptance and integration of perspectives}

Often a participatory process starts with a predefined problem that may not be shared by all stakeholders. This reduces the willingness of these stakeholders to participate and commit themselves. Moreover, it may result in quite narrow, non-integrated solutions. Hence, willingness to accept and integrate different perspectives on the problem is important.

\section{Financial resources}

Limited time and finances of both organizers and other stakeholders often hinder effective participation processes. This should be considered early on in the planning process.

Fig. 1 Issues that influence participatory processes (adapted from Mostert et al. 2009)

2009; Olsson et al. 2007). Recent literature has shown the effectiveness of concepts such as the "boundary work" that focuses at the interface between different communities to facilitate a dialogue while maintaining their identities (Cash et al. 2003; Clark et al. 2016). This approach has been applied in different contexts and merged with the ES concept (Adem Esmail et al. 2017; Adem Esmail and Geneletti 2017), supporting the implementation of an adaptive water management (Pahl-Wostl et al. 2011). In this sense, WES concept is a useful tool towards a more functional and holistic approach (Blancher et al. 2011; Stosch et al. 2017) where a higher level of participation is achieved by using a common language to co-define water management solutions.

Stakeholder involvement usually focuses on the most powerful and interested groups to be represented in the decision-making process (Johnson et al. 2009; Mendelow 1981) but this approach depicts a static picture of the society where low priority stakeholders (i.e. parts of community characterized by low importance and influence in the decision-making, usually not involved in a collaborative water planning process) can hardly take part in the dialogue. As suggested by Lindsay et al. (2019), the engagement of community members who are less likely to be represented in participatory processes can help integrating the perspectives carried out by the more proactive members and can facilitate the development of planning strategies aligned with broader community aspirations. Therefore, this study focuses on low priority stakeholders as a carrier of local knowledge that can introduce an alternative point of view in the decision-making process, strengthening and complementing the participatory process already sustained by the WFD.

The assimilation of local/traditional knowledge in water management has already shown its effectiveness in many previous experiences especially located in developing countries (Horlemann and Jafari Berenji 2017; Castelli et al. 2018) but it is mostly neglected in WFD implementation.

Kastens and Newig (2008) highlighted that if the seriousness of the process and the stakeholder commitment is assured, WFD implementation can become a great chance for stakeholder involvement and can give weak actors the chance to state their interests. As highlighted by Morrison (2003) a mechanism to welcome new stakeholders into the process 
is the key to successfully develop a participatory action and to assure greater outreach to nonwater groups. In this sense, the participatory identification and selection of WES appears as an effective starting point for stimulating the participation and the discussion between stakeholders (Steger et al. 2018; Paudyal et al. 2015) and preserving their commitment.

The present work was realized within the "WaterValues" Project, financed by the Tuscany Region (Italy) in the framework of the Regional Law for Participation 46/2013. Among others, the aims of the law are "to promote forms and instruments of democratic participation to guarantee and make effective the right to participate in the elaboration and formation of regional and local policies; to strengthen the quality of democracy and its decision-making processes, through the enhancement of innovative models of participatory democracy and deliberative democracy; to realize the diffusion and concrete realization and experimentation of new practices and experiences of citizen involvement in the construction of public choices and collective decisions" (Regione Toscana 2013a, translated). Built over the experiences of French "Public Debate" experiences for participation (Galet-Lalande 2004), the Law 46/2013 represent a first attempt of transporting a model of deliberative democracy into administrative processes (Floridia 2008).

Our approach took advantage of this regional regulatory framework, providing a sound basis to facilitate a shared watershed planning process (implementing the WFD) where the instances of population are combined with the decision makers perspectives using the WES concept to facilitate knowledge circulation and solutions co-definition. The specific objectives of the study are: (1) to carry out an analysis of the society perception (with a specific focus on low priority stakeholders) regarding the value of water resources in the territory by utilizing the WES concept (2) to identify and map WES through focus groups and participatory WES mapping; and (3) to integrate results of objectives (1) and (2) to inform water decision makers and to support the uptake of the participatory process results into the future water management strategies.

\section{Materials and Methods}

\subsection{Study Area}

This study focused on Figline and Incisa Valdarno - FIV Municipality, Tuscany Region, Italy (Fig. 2), a territory located in the central part of the Arno river basin.

The Arno river basin has a total surface of about $9116 \mathrm{~km}^{2}$, with a length of $214 \mathrm{~km}$ for the main river channel and an average elevation of $353 \mathrm{~m}$ a.s.l.. The river flows from East to West, from the Apennines mountain ridge to Tyrrenian Sea. Average rainfall amounts in the watershed ranges from $800 \mathrm{~mm}$ to about $1800 \mathrm{~mm}$ on the Apennine ridge (Caporali et al. 2005), while average flow at the outlet equals to $90 \mathrm{~m}^{3} / \mathrm{s}$ (Autorità di Bacino Distrettuale dell'Appennino Settentrionale 2019b).

FIV municipality falls within the basin, with a hilly territory of $98 \mathrm{~km}^{2}$ that include small left-bank tributaries catchments (Fig. 2c). The municipality has a total population of around 23,400 inhabitants, and the present administrative setting of the municipality originated in 2014 by the fusion of two pre-existent municipalities, "Figline" and "Incisa Valdarno". As shown by Regione Toscana land use data of 2016 (Regione Toscana 2019), the territory has predominant forest cover, while human settlements are located along the riverbank (Fig. 3). Arable land present in the municipality is reported to be completely non-irrigated on Corine 


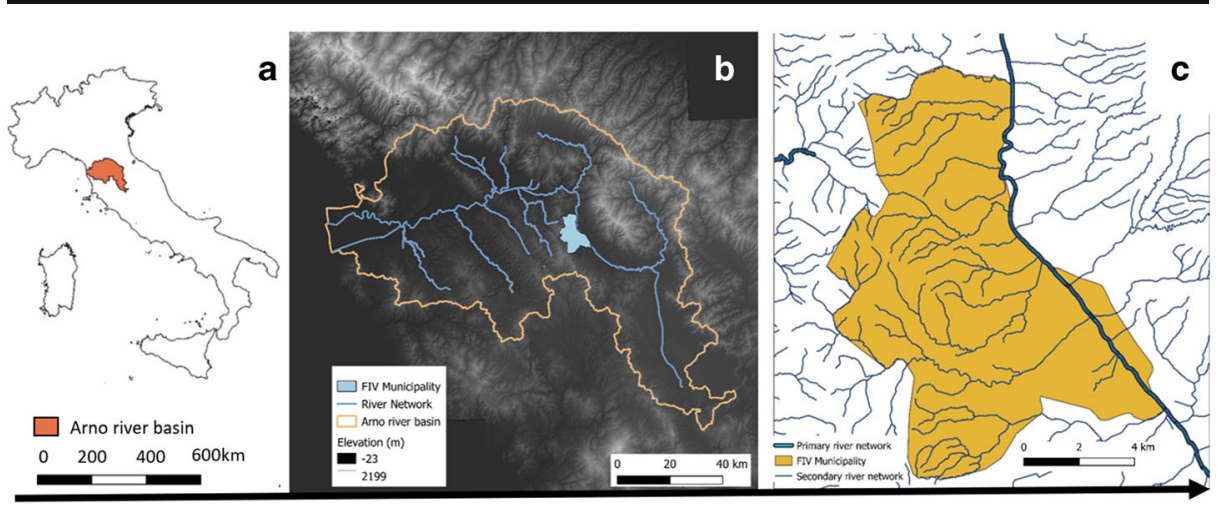

Fig. 2 Study area: a Location of Arno river basin; b Position of "Figline e Incisa Valdarno" (FIV) Municipality within the Arno river basin (Data sources: Autorità di Bacino Distrettuale dell'Appennino Settentrionale 2019a; Farr et al. 2007); c River network (Data sources: Autorità di Bacino Distrettuale dell'Appennino Settentrionale, 2019a, b; Regione Toscana 2019)

Land Cover map 2018 (not shown), while permanent crops are predominantly olives groves and vineyards, which received irrigation only in emergency (Copernicus 2019).

According to the monitoring data provided by the River Basin Authority of the Northern Apennines District (Autorità di Bacino Distrettuale dell'Appennino Settentrionale 2015), the quality of water bodies in the municipality is heterogeneous. The Arno River suffers the consequences of upstream pollution that results in a low ecological and chemical status while Arno tributaries in the municipality show a sufficient ecological status and a good chemical status. As far as groundwater is concerned, the municipality is characterized by the presence of

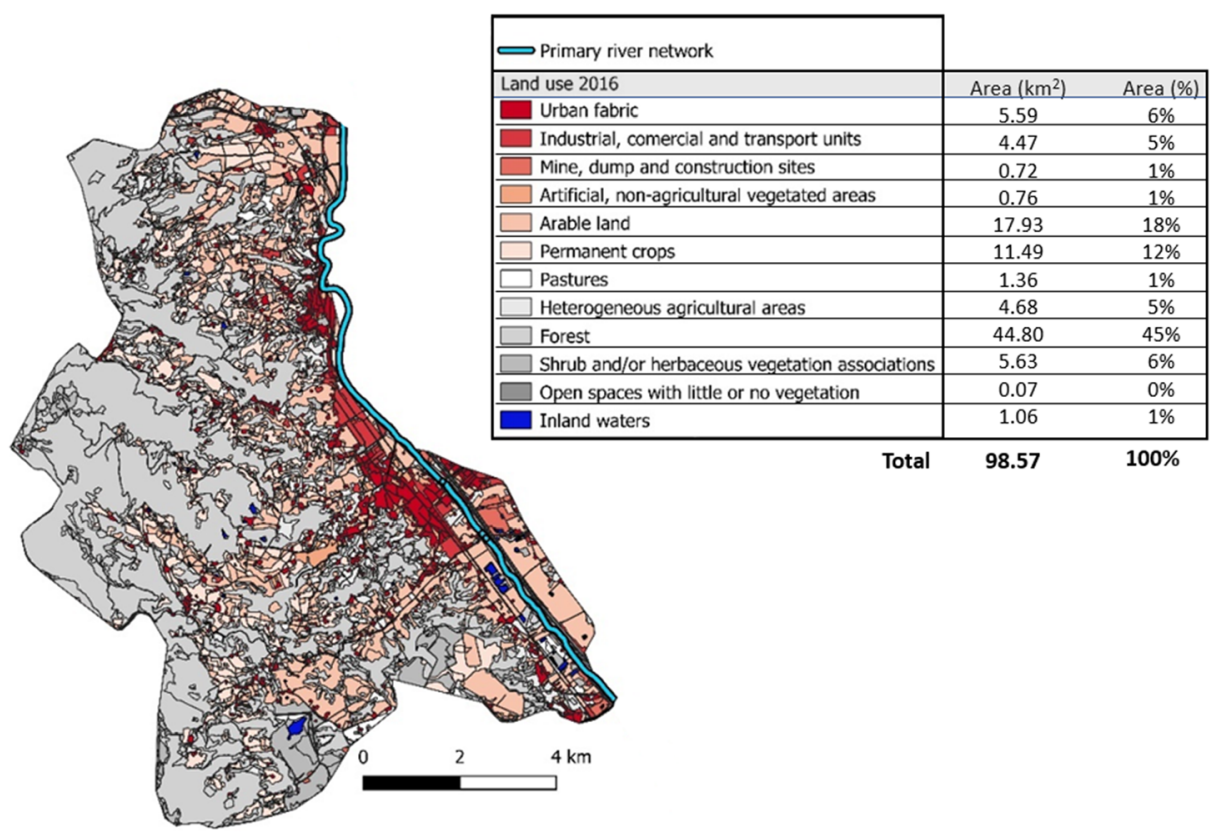

Fig. 3 "Figline e Incisa Valdarno" (FIV) municipality Land cover map (2016) and table. Source: Regione Toscana (2019) 
a single aquifer in the valley area. From a quantitative point of view the underground resource appears to be abundant but the quality is low due to the presence of metal contaminants.

Water represents a fundamental component of the economy of the area: besides the domestic consumption, water is used for industry and agriculture. The river, together with its riparian areas, contributes to the landscape of the area and its touristic vocation. At the same time, water can be a threat for the territory, especially due to hydrological extremes. Recent droughts events have jeopardized the agricultural sector and caused water rationing during summer in FIV municipality. On the other hand, the case study area is characterized by high hydraulic risk as confirmed by several past flood events (e.g. the flood event of November 1966) that led to the realization of two detention ponds realized upstream of the municipality (Galloway et al. 2020).

\subsection{WES Assessment through a Participatory Process}

This study aims at developing a participatory assessment of WES that merge ES assessment (e.g. Everard and Waters 2013) and focus group discussion (Nyumba et al. 2018) structures in a 4-tiered methodology (Fig. 4): (1) biophysical assessment of the study area; (2) analysis of the population and identification of the stakeholders to be involved in the focus groups; (3) organization of focus groups to carry out: (3-a) participatory identification of WES, (3-b) their mapping in the study area and (3-c) identification of valuable WES characterised by a critical status; (4) participatory scenarios analysis where different management options are highlighted.

\subsubsection{Steps (1)-(2): From the Preliminary Biophysical Assessment to the Stakeholder Identification}

The biophysical assessment was carried out based on the information contained in the River Basin Management Plan (RBMP) produced by the River Basin Authority of the Northern Apennines District (Autorità di Bacino Distrettuale dell'Appennino Settentrionale 2015). Following the WFD, the RBMP provides a detailed analysis of the status of each surface and underground water body in the district and it was used to derive a simplified summary of the main characteristics of water resources in the area of study by means of quantitative and

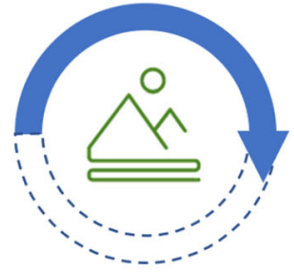

STEP 1 Preliminary phase

- Biophysical assessment

- Participation guide

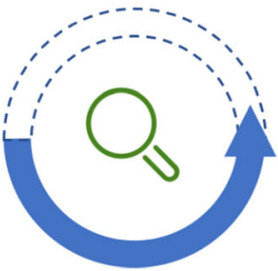

STEP 2 Stakeholders identification

Fig. 4 Overview of the participatory methodology

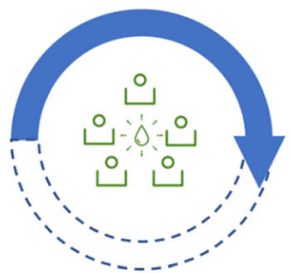

STEP 3

Focus groups

- WES inventory

- WES mapping

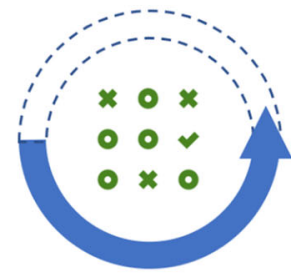

STEP 4 Participatory scenario analysis

- Critical WES evaluation

- Scenarios definition 
qualitative indicators (e.g. quality status of water bodies, consumption of water resources). The biophysical assessment was embedded in the Participant Guide (Regione Toscana 2018a) to adequately inform citizenship and participants over the themes of the participatory process. In addition to the biophysical assessment of the territory, the Guide also included information regarding the Regional Law on participation (46/2013) and an overview on WES concept.

At the same time, the stakeholder identification and recruitment were carried out aiming at assuring the general public an opportunity to 'voice' their view (Razzaque 2009) and including the part of society usually not involved in the water management discourse.

In accordance with the objectives of the study (i.e. assessing WES from the perspective of low priority stakeholders), the preliminary selection of the participants was oriented to a citizen group of mixed composition (in terms of age, sex, education) that were contacted by telephone and email. Due to the difficulties in reaching the targeted number of participants per focus groups (i.e. 6-8 according to Krueger and Casey 2000) with this approach, the participatory process shifted to the involvement of local associations. The associations involved were 4: "Prociv - Protezione Civile", composed by local civil protection servants; "Il Giardino", cultural association of retirees; Association "Soci Coop Figline", composed by local associated of the largest system of Italian food consumers' cooperatives; "Circolo fotografico Arno", a photographers club located in FIV municipality with a specific interest on riverine environment.

This approach aimed at engaging low priority stakeholders through the involvement of multiple community champions (i.e. local associations) to target those groups that, despite their marginalized role, have the motivation to trigger a shift in governance starting from at a local level (Lindsay et al. 2019). These community champions catalyzed the organization of "tailor-made" meetings with their members. Although this approach has some limitations due the difficulties of assuring a wide stakeholders' accessibility (Krueger and Casey 2000), the chosen associations allowed to carry out a sampling in line with the objectives of the study due to their heterogeneous composition. This resulted into a hybrid approach aimed at disrupting one of the main limitations of a participatory process based on a pure "community champions" involvement, namely, to select a very homogeneous class of participants, with still a limited vision of the project (Lindsay et al. 2019).

\subsubsection{Step (3): Focus Groups for WES Assessment}

Participants received the Participant Guide and were firstly involved in a focus group discussion in order to identify the main WES provided in the FIV municipality and for the municipality itself (i.e. WES provided in other parts of the watershed but beneficial to FIV territory). This first phase had the objective of allowing the participants to identify WES by themselves and of obtaining major engagement, as prescribed by Boeraeve et al. (2018). Meeting were also attended by facilitators and WES experts to support the discussion and avoiding 'powerful' participant to block the discussion only on few WES (Boeraeve et al. 2018). For each WES identified, participants were asked to locate its generation area on a map (similarly to Delgado-Aguilar et al. 2017), adopting an easy-to-use tool such as Google Earth (Brown and Fagerholm 2015; Stocker et al. 2012). Google Earth windows were projected during the focus group, allowing further discussion, engagement, and cross-checking of the information. This supported the identification of the main WES hotspots, i.e. areas that provide large proportions of a service (Egoh et al. 2008; Schröter and Remme 2016). Moreover, participants were asked to determine WES actual value (from 1 - low value due to socioecological issue; 5 - high value with no problem related to WES provision), and criticisms 
hindering the present provision. In a post-analysis phase, rankings from 1 to 5 were linearly rescaled to 1 to 3 to simplify the scenario analysis (step 4).

Four participatory tailor-made meetings were organized in the municipality, from May 28th to June 1st, 2018. Reports of all meetings were compiled and the results of the participatory process were made publicly available (Regione Toscana 2018b).

\subsubsection{Step (4): Participatory Scenario Analysis}

Following a roadmap similar to the one presented by Langemeyer et al. (2018), a final participatory meeting was held on June 12th, 2018, in order to cross-check the findings of the focus groups and to frame suitable actions for developing future land and water development strategies in the municipality. Besides all the participants of the focus groups, the meeting was attended by decision makers to foster the uptake of the low priority stakeholders perspective into future planning. The meetings included: i) a reporting phase on the findings of each focus group, ii) a participatory identification the most critical WES, iii) a discussion on the potential solution and the drafting of potential intervention scenarios.

A total of 43 informants were involved within the entire participatory process, excluding experts, facilitators and decision makers (Table 1).

\section{Results}

\subsection{WES Inventory}

The four focus groups allowed the definition of multiple inventories from which is possible to derive useful information regarding the different perception that citizen have on WES. During the discussion, with the support of facilitators, participants shared their opinion on waterrelated ecosystem status in the municipality and the different values that water resources can acquire according to the beneficiary needs. In this sense, the focus groups provided a WES supply and demand integrated analysis, including a qualitative evaluation of the main hotspots in the area. For each class of services (i.e. regulating, supporting, provisioning, cultural) a list of the most important WES were elaborated identifying the area of production, the status of ecosystem providing each service and, in case of a compromised ecosystem, the sources of criticality.

Starting from Provisioning services (Table 2), the focus groups underlined the importance of water availability to support basic needs such as drinking water supply. This WES, based on the water resources withdrawn from Arno River, shows a medium level of criticality strictly connected to the hydrological regime characterized by low summer flows that determine

Table 1 Participants involved in the meetings

\begin{tabular}{lcccccr}
\hline Age & Males & Females & Males $(\%)$ & Females $(\%)$ & Total & Total $(\%)$ \\
\hline $18-35$ & 5 & 1 & 11.6 & 2.3 & 6 & 14.0 \\
$36-60$ & 11 & 3 & 25.6 & 7 & 14 & 32.6 \\
$>60$ & 12 & 5 & 27.9 & 11.6 & 17 & 39.5 \\
Not specified & 4 & 2 & 9.3 & 4.7 & 6 & 14.0 \\
Total & 32 & 11 & 74.4 & 25.6 & 43 & 100.0 \\
\hline
\end{tabular}


sporadic events of water distribution breakdowns. During the discussion the major role of some hydraulic structures was emphasized, such as the importance of upstream reservoirs (i.e. Levane and La Penna dams). The high-quality public water fountains installed in recent years by the municipality in collaboration with the local water supply company was also recognized as an important asset to improve access to water. Participants stressed the importance of social horticulture activities in the municipality and the strong connection of this activity to the availability of water resources. In this case the identified WES is not showing any sources of criticalities because it is dependent to groundwater abstraction through shallow wells that assure a constant supply of water during throughout the year. Furthermore, the importance of several small size lakes scattered in the municipality territory has been recognized as an important resource to provide fire protection during summer months.

Regarding the supporting WES (Table 3), participants made remarks regarding the present state of Arno River in the municipality, stressing the differences between the main water body (that is suffering high level of pollution and provides low support to aquatic biodiversity) and its main tributaries (that have higher water quality, as confirmed by the presence of high variety of species).

The artificial lakes realized in the 80's for the gravel mining industries are now perceived as an important biodiversity hotspot due to the presence of multiple bird species. Indeed, this area was declared a natural protected area after its reconversion and now hosts important groups of protected heron species (Regione Toscana 2013b). Being the water quality the main issue of the Arno River in the area, the existing wastewater treatment plant was recognized as a key element. Even though it represents a measure to reduce an impact rather than a source of WES (thus not included in the list) it shows the awareness of local population on the importance of having well-functioning wastewater management.

The focus group discussion on regulating WES mainly focused on flood regulation. This is due to the history of the territory of FIV that have been strongly affected by the catastrophic flood event of 1966 (Caporali et al. 2005). The inventory of regulating WES (Table 4) reflects this sensitivity and the awareness of population on the importance of territory maintenance to provide flood regulating services. In addition, focus groups highlighted the role of existing infrastructures in providing regulating WES and identified the drainage network as the main source of criticalities due to its insufficient capacity to cope with high intensity rainfall events.

Cultural WES were the most debated services in each focus group. All participants confirmed the population-ecosystem bonding role of Arno River and its tributaries pointing

Table 2 Provisioning WES identified during the four focus groups. Status from 1 - low value due to socioecological issue; to 3 - high value with no problem related to WES provision

\begin{tabular}{|c|c|c|c|c|}
\hline Type of WES & Description & Production & Status & Criticality \\
\hline Provisioning & $\begin{array}{l}\text { Irrigation for private } \\
\text { horticultures }\end{array}$ & Shallow wells in Arno aquifer & 3 & \\
\hline Provisioning & $\begin{array}{l}\text { Irrigation for communal } \\
\text { horticultures }\end{array}$ & Shallow wells in Arno aquifer & 3 & \\
\hline Provisioning & Drinking water supply & Arno river & 2 & $\begin{array}{l}\text { Lack of water during } \\
\text { summer }\end{array}$ \\
\hline Provisioning & Drinking water supply & Public fountains & 3 & \\
\hline Provisioning & Drinking water supply & $\begin{array}{l}\text { Dams in upstream areas } \\
\text { (Levane, La Penna) }\end{array}$ & 3 & \\
\hline Provisioning & Firefight protection & Lakes in the municipality & 3 & \\
\hline
\end{tabular}


Table 3 Supporting WES identified during the four focus groups. Status from 1 - low value due to socioecological issue; to 3 - high value with no problem related to WES provision

\begin{tabular}{lllll}
\hline Type of WES & Description & Production & Status & Criticality \\
\hline Supporting & Support to aquatic biodiversity & Arno tributaries & 3 & \\
Supporting & Support to aquatic biodiversity & Arno river & 1 & Low quality of water \\
Supporting & Support to biodiversity & Lakes generated by excavations & 3 & \\
\hline
\end{tabular}

out the fundamental importance of water in underpinning social and cultural values. During the discussion, recreation on river embankments and sport fishing activities emerged as the main components of the overall cultural WES provide by the Arno River. The main factors jeopardizing the provision of these services are the low quality of water (that compromises the presence of fishes in the river) and the reduced accessibility of the river side. In addition, the small size lakes previously identified were included in the list of the main hotspots for recreational activities (Table 5).

The result of the WES inventory phase is a list of WES that reflects each focus group perception on the different values that water can have in the territory and it has been the basis to carry out the WES mapping.

\subsection{Participatory WES Mapping}

The second phase of the focus groups allowed the participants to translate the WES inventory previously realized into a spatial identification of the main WES hotspots. Taking advantage of the Google Earth platform participants were able to map the main sources of the four different WES classes, pinpointing the main criticalities.

Results show that the highest concentration of regulating and supporting WES supply is located along the main channel of the Arno River and its tributaries (Fig. 5). In particular, all the five tributaries of Arno River in FIV municipality (namely Borro di San Cipriano, Torrente del Cesto, Borro di Ponterosso, Fosso del Burchio and Fosso del Selceto) are key elements of the regulating and supporting function of the ecosystem. On the Arno river main channel, the areas located nearby the weirs and the detention pond are mapped as the main sources of regulating WES while the Garzaia Artificial lake is main hotspot for supporting WES.

The Arno river main channel is also perceived as the main source of cultural WES, with population using the left side embankment and the surrounding areas for recreational activities.

Table 4 Regulating WES identified during the four focus groups Status from 1 - low value due to socioecological issue; to 3 - high value with no problem related to WES provision

\begin{tabular}{lllll}
\hline Type of WES & Description & Production & Status & Criticality \\
\hline Regulating & Climate regulation & Arno tributaries & 3 & \\
Regulating & Erosion control & Weirs on Arno tributaries & 3 & \\
Regulating & Flood protection & Weirs on Arno tributaries & 3 & \\
Regulating & Flood protection & Dams in upstream areas (Levane, La Penna) & 3 & Low maintenance \\
Regulating & Flood protection & Drainage network & 2 & 3 \\
Regulating & Flood protection & Land use setting & 3 & \\
Regulating & Flood protection & Arno tributaries & 3 & \\
Regulating & Flood protection & Flood detention basins & 3 & \\
Regulating & Flood protection & Weir on Arno river (Incisa) &
\end{tabular}


Table 5 Regulating WES identified during the four focus groups. Status from 1 - low value due to socioecological issue; to 3 - high value with no problem related to WES provision

\begin{tabular}{|c|c|c|c|c|}
\hline Type of WES & Description & Production & Status & Criticality \\
\hline Cultural & Recreational (sport fishing) & Lakes in the municipality & 3 & \\
\hline Cultural & Recreational (sport fishing) & Arno river & 1 & Low quality of water \\
\hline Cultural & Recreational (riverside) & Arno river & 3 & \\
\hline Cultural & Recreational (riverside) & Arno river & 1 & $\begin{array}{l}\text { Partial accessibility to riverside } \\
\text { (downstream Incisa Area), } \\
\text { Low quality of water }\end{array}$ \\
\hline Cultural & General cultural value & Arno river & 1 & Low quality of water \\
\hline
\end{tabular}

Provisioning WES are mainly located in the urbanized part of the municipality where focus groups mapped social gardens and public fountains. Furthermore, the main lakes that provide both provisioning (firefight protection) and cultural (sport fishing activities) services were identify and pinpointed (Fig. 6).

All the information collected in the focus groups was then converted into a spatial dataset that can be used in GIS environment to be integrated with other information (e.g. Northern Apennines District RBMP, the Municipality Master Plan) to provide valuable information within the spatial planning and water management process.

\subsection{Critical WES Identification}

The identification of the most critical WES and the corresponding production areas that need to be improved was carried out discussing the results of the focus groups in a plenary participatory meeting. The evaluation of the criticality level was based on the comparison between the demand of each WES (relative importance perceived by the participants in the focus groups) and the associated capacity of the ecosystem to provide it (ecosystem conditions).

A full agreement was found on the importance of preserving a good level of water quality to provide the main perceived WES, i.e. cultural services (recreational and fishing activities) and supporting services (support to aquatic biodiversity). Furthermore, the importance of

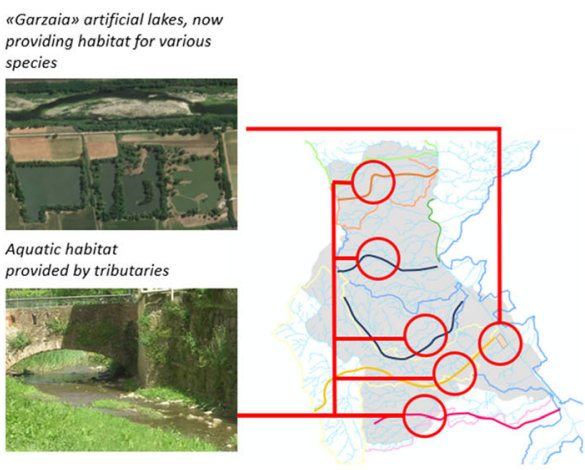

a Supporting WES

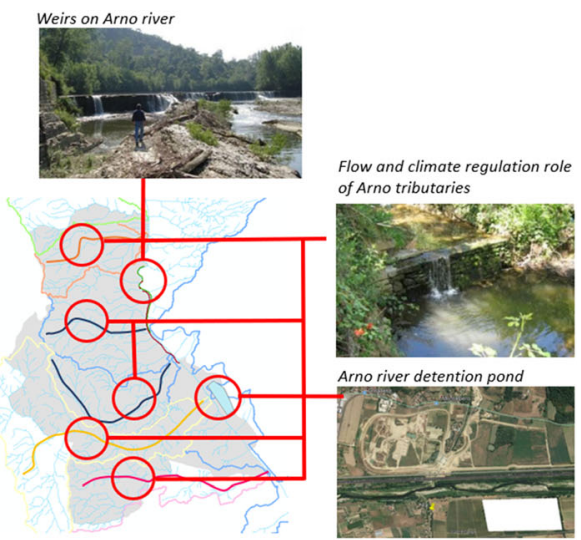

b Regulating WES

Fig. 5 Supporting (a) and Regulating (b) WES participatory maps 

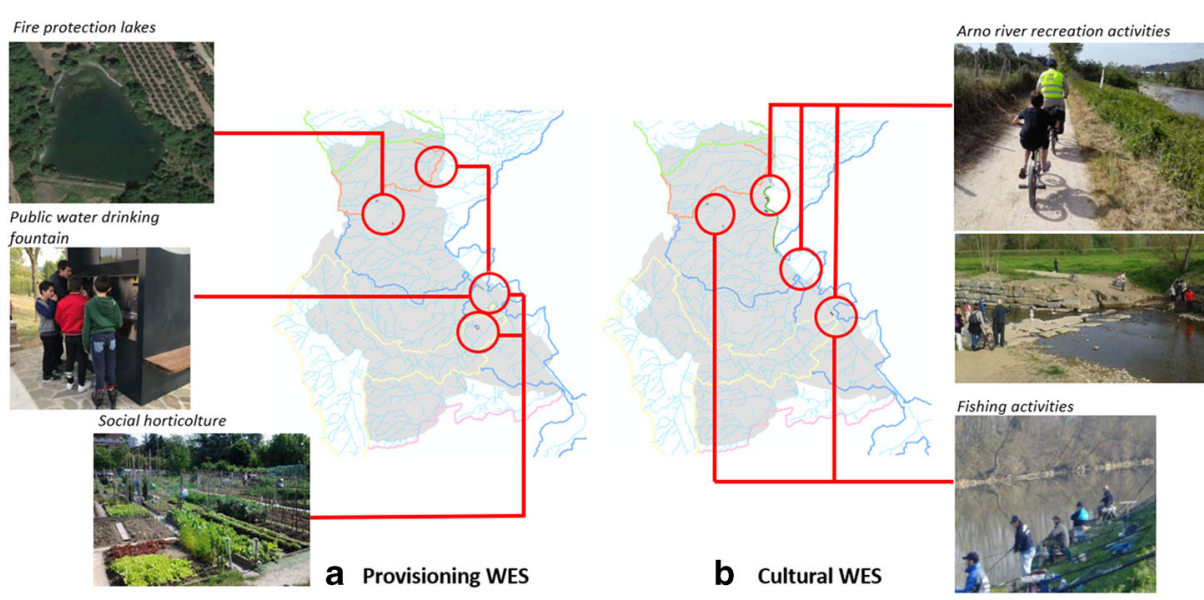

Fig. 6 Provisioning (a) and cultural (b) WES participatory maps

improving riverside area was recognized as a key element to assure the effective WES enjoyment (Table 6).

\subsection{Participatory Scenario Analysis}

The identification of the critical WES served as the starting point for the discussion on the potential intervention scenarios, aiming at merging the focus groups perspectives with the strategies to be developed by the attending decision makers (i.e. FIV municipality, the River Basin Authority and the local Land Reclamation Authority). Two connected scenarios were discussed during the plenary meeting, corresponding to the main criticalities identified. The first one was related to the low status of water quality in the Arno main channel that undermines the capacity of the ecosystem to support the aquatic biodiversity and limits its possibility to provide cultural services. This issue was well recognized by the involved decision makers that have already set up strategies to achieve the WFD quality objectives. However, the results of the participatory process justify additional measures to ensure that this achievement goes towards the direction of maximizing the WES produced by the river ecosystem. Indeed, the developed scenario included the idea of experimenting Payment for ES approach (PES, Wunder and Wertz-Kanounnikoff 2009) that actively involves local stakeholders into the definition and implementation of measures to improve water quality

Table 6 Critical WES summary table. Status from 1 - low value due to socio-ecological issue; to 3 - high value with no problem related to WES provision

\begin{tabular}{|c|c|c|c|c|}
\hline Type of WES & Description & Production & Status & Criticality \\
\hline Cultural & Recreational (sport fishing) & Arno river & 1 & Low quality of water \\
\hline Cultural & Cultural value & Arno river & 1 & Low quality of water \\
\hline Support & Support to aquatic biodiversity & Arno river & 1 & Low quality of water \\
\hline Cultural & Recreational (riverside) & Arno river & 1 & $\begin{array}{l}\text { Partial accessibility to riverside } \\
\text { (downstream Incisa Area), } \\
\text { Low quality of water }\end{array}$ \\
\hline Provisioning & Drinking water supply & Arno river & 2 & Lack of water during summer \\
\hline Regulating & Flood protection & Drainage network & 2 & Low maintenance \\
\hline
\end{tabular}


and support WES production, converting the WFD "polluter pays" principle into the "beneficiary pays" principle.

The second analysed scenario dealt with the recreational WES on riverside, trying to identify strategies that operationalize the approach developed in the first scenario. In fact, dealing with a specific WES that is particularly close to participant perception allowed for the identification of specific measures to be implemented. In particular, the idea of participatory maintenance activity of the embankment was discussed, exploring the possibility of setting up specific investment in the form of a PES. This kind of intervention was positively received by the decision makers that underlined the possibility of integrating this strategy with the existing maintenance measures and creating synergies with the ongoing River Contracts (Voghera 2015) experiences.

\section{Discussion}

Public participation is a key element in the application of EU WFD (Ridder and Pahl-Wostl 2005; Ruiz-Villaverde and García-Rubio 2017). Following this principle, the present work takes advantage of the institutional instrument of the Regional Law for Participation 46/2013 of Tuscany Region (Regione Toscana 2013a) to foster citizen participation in river basin management and planning. Although some early studies pointed out that the Regional Law was rather having symbolic value but not influencing public decision making, also excluding more active minorities (Freschi and Raffini 2008; Cellini et al. 2010), it was successfully applied in several cases, triggering participatory processes that improved the environmental sustainability of single infrastructural projects, also informing the population over the impacts of such works (Casini 2017). Instead of focusing on a specific infrastructure, our application aimed at supporting the public debate in the elaboration of shared watershed planning strategies based on WES assessment. Some experiences of river basin management in Italy, already took advantage of participative laws such as Law 46/2013. However, most of these are focused on the establishment of river basin contracts (Bocchi et al. 2012; De Luca and Orlotti 2018; Regione Toscana 2018c; LIFE-REWAT 2019). The WaterValues project represents one of the first main cases of public participation for the evaluation of WES to inform future RBMP at a larger scale.

Our approach focused on low priority stakeholders, which are usually not involved in the decision-making processes (Freschi and Raffini 2008). This was done by engaging them during the ordinary meetings of their own association (section 2.2.1). Holding separated meetings with association safeguarded the diversity of perceptions, favoring the expression of multiple voices that could have been overlooked by more powerful stakeholders in a plenary meeting and/or limited by time (Cleaver 1999). As a consequence, it should be mentioned that the participatory process implicitly focused only on the associations involved in the project. This implies that the analysis should be integrated with other stakeholders perspectives to derive a shared management strategy that is representative of the entire range of needs in the area.

The concept of WES was the key to facilitate the participation of stakeholders, as already noted by Blancher et al. (2011). It established a common language between participants and decision makers, overcoming the communication barriers that are often presents between these two groups (Ruiz-Villaverde and García-Rubio 2017). Moreover, the process fully involved decision makers in its last phase of the process, considering their fundamental importance but 
involving them not with a leadership position, in order to safeguard public participation (Van Ast and Gerrits 2016).

The citizenship of FIV Municipality was active and reactive during the participatory process. Noticeably, the highest discussion was over cultural WES, while high attention was also given to flood reduction services. Clearly, the results of each of the focus groups realized reflected the peculiarities of the group and were influenced by the age, level of education and personal attitudes of the participants. As an example, a strong polarization emerged in the opinion of those who experienced the terrific flood of 1966 and who strongly support the importance of regulating WES in the territory. It has also to be noticed that the list of provisioning WES does not include other important services such as the agricultural production that was not mentioned during the focus groups discussion. This is a consequence of the approach adopted in this study that was mainly focused in revealing the low priority stakeholder perspectives rather than to produce a thorough WES assessment.

Most of the WES in critical status were connected to the low water quality of the main water body (Arno River) and to the low usability of part of the riverside for recreational purposes. The structure of the participatory process favored the discussion of these latter issues (emerged in the focus groups) and the definition of a shared vision over the possible management solutions that can be adopted in the RBMP. The participatory process also determined further practical suggestions to be implemented in the short term (section 3.4) namely PES schemes and a further participatory process for determining future management strategies within a River Contract scheme. Our findings confirms that the ES concept can support the planning and management of freshwater related socio-ecological systems (Palomo et al. 2011; Castelli et al. 2017), as for other cases including forest (Paudyal et al. 2015) and marine environment (Lopes and Videira 2013).

\section{Conclusion}

This work presented a first experience of a formal and institutionalized participation process realised building on the WES concept within the framework of the Regional Law for Participation 46/2013 of Tuscany Region. Our study aimed at integrating citizenship participation and WES evaluation to support Arno River basin management, fostering the implementation of the WFD participatory component (art.14).

Our results included the identification of the main WES and their participatory evaluation in FIV Municipality (Tuscany Region, Italy). WES emerged as a very suitable concept to establish a productive dialogue over water and river basin management among stakeholders and decision makers. Indeed, the discussion over relevant WES in a critical status (not adequately provided by the river ecosystem) allowed the identification of different management scenarios, namely the establishment of a Payment for Ecosystem Services (PES) scheme to lower the impact of productive activities polluting the river, and the development of participatory maintenance activities for assuring the sustainable management of recreational and high-biodiversity riparian areas.

The WES participatory assessment is an adaptative approach that can be replicated at different scales and under various contexts to reveal the multiple relationships between society and water resources. This will eventually support the achievements of WFD objectives with the co-definition of intervention measures that seek an ideal convergence of different perspectives leading to an effective watershed management. 
Acknowledgements This study was realized thanks to the funding provided by to Tuscany Region for local participatory processes (Regione Toscana- Delibera n. 36 del 30 agosto 2017). The authors want to thank Lorenzo Tilli and the Municipality of Figline e Incisa Valdarno for their willingness and dedication throughout the entire project implementation, and ReteSviluppo team (Bianca Cinelli, Marco Dugini, Carmelita Breccione Mattucci and Lapo Cecconi) who organized the focus groups and the communication activities. Moreover, the authors are grateful to the reviewers and editors for their valuable comments and suggestions. Open access funding provided by Università degli Studi di Firenze within the CRUI-CARE Agreement.

\section{Compliance with Ethical Standards}

\section{Conflict of Interest None.}

Open Access This article is licensed under a Creative Commons Attribution 4.0 International License, which permits use, sharing, adaptation, distribution and reproduction in any medium or format, as long as you give appropriate credit to the original author(s) and the source, provide a link to the Creative Commons licence, and indicate if changes were made. The images or other third party material in this article are included in the article's Creative Commons licence, unless indicated otherwise in a credit line to the material. If material is not included in the article's Creative Commons licence and your intended use is not permitted by statutory regulation or exceeds the permitted use, you will need to obtain permission directly from the copyright holder. To view a copy of this licence, visit http://creativecommons.org/licenses/by/4.0/.

\section{References}

Adem Esmail B, Geneletti D (2017) Design and impact assessment of watershed investments: an approach based on ecosystem services and boundary work. Environ Impact Assess Rev 62:1-13

Adem Esmail B, Geneletti D, Albert C (2017) Boundary work for implementing adaptive management: a water sector application. Sci Total Environ 593:274-285

Autorità di Bacino Distrettuale dell'Appennino Settentrionale (2015) Piano di Gestione delle Acque dell'Autorità di Bacino Distrettuale dell'Appennino Settentrionale

Autorità di Bacino Distrettuale dell'Appennino Settentrionale (2019a) OpenData. http://www.adbarno. it/opendata/. Accessed on 29 Dec 2019

Autorità di Bacino Distrettuale dell'Appennino Settentrionale (2019b) Il bacino in numeri. http://www.adbarno. $\mathrm{it} / \mathrm{adb} /$ ?page id=1114. Accessed on $31 \mathrm{Dec} 2019$

Berkes F (2009) Evolution of co-management: role of knowledge generation, bridging organizations and social learning. J Environ Manag 90(5):1692-1702

Blancher P, Vignon C, Catalon E et al (2011) Ecosystem services approach for water framework directive implementation. WIT Trans Ecol Environ 148:75-86. https://doi.org/10.2495/RAV110081

Bocchi S, La Rosa D, Pileri P (2012) Agro-ecological analysis for the EU water framework directive: an applied case study for the river contract of the Seveso Basin (Italy). Environ Manag 50:514-529. https://oi. org/10.1007/s00267-012-9925-3

Boeraeve F, Dufrene M, De Vreese R et al (2018) Participatory identification and selection of ecosystem services: building on field experiences. Ecol Soc 23. https://doi.org/10.5751/ES-10087-230227

Brauman KA, Daily GC, Duarte TKE, Mooney HA (2007) The nature and value of ecosystem services: an overview highlighting hydrologic services. Annu Rev Environ Resour 32:67-98

Brown G, Fagerholm N (2015) Empirical PPGIS/PGIS mapping of ecosystem services: a review and evaluation. Ecosyst Serv 13:119-133. https://doi.org/10.1016/j.ecoser.2014.10.007

Caporali E, Rinaldi M, Casagli N (2005) The Arno River floods. Giornale di Geologia Applicata 1:177-192

Cash DW, Clark WC, Alcock F, Dickson NM, Eckley N, Guston DH, ..., Mitchell RB (2003) Knowledge systems for sustainable development. Proc Natl Acad Sci, 100(14), 8086-8091

Casini C (2017) Citizen engagement for sustainable development of port cities: the public debate about development projects of Livorno port. Lect Notes Comput Sci 10409 LNCS:416-429

Castelli G, Minelli A, Tefera ML et al (2017) Impacts of Rainwater Harvesting and Rainwater Management on Upstream - Downstream Agricultural Ecosystem Services in Two Catchments of Southern Tigray, Ethiopia. Chem Eng Trans 58:685-690. https://doi.org/10.3303/CET1758115

Castelli G, Bresci E, Castelli F, Hagos EY, Mehari A (2018) A participatory design approach for modernization of spate irrigation systems. Agric Water Manag 210:286-295. https://doi.org/10.1016/j.agwat.2018.08.030 
Cellini E, Freschi AC, Mete V (2010) Who deliberates? Questioning the political meaning of a participatorydeliberative experimentation. Ital Polit Sci Rev 40:113-144. https://doi.org/10.1426/31674

Cernesson F, Echavarren JM, Enserink B, Kranz N, Maestu J, Maurel P, Mostert E, Otter H, Patel M, Ridder D, Schlussmeier B, Tàbara JD, Taillieu T, Wolters H (2005) Learning together to manage together. Improving participation in water management. HarmoniCOP, pp.99, 2005, Harmonising Collaborative Planning, 3-00016970-9. 〈hal-02588072〉

CICES (2015) http://cices.eu/. Accessed 29 Dec 2019

Clark WC, Tomich TP, Van Noordwijk M, Guston D, Catacutan D, Dickson NM, McNie E (2016) Boundary work for sustainable development: natural resource management at the consultative group on international agricultural research (CGIAR). Proc Natl Acad Sci 113(17):4615-4622

Cleaver F (1999) Paradoxes of participation: questioning participatory approaches to development. J Int Dev 11: $597-612$

Coates D, Pert PL, Barron J, Muthuri C, Nguyen-Khoa S, Boelee E, Jarvis DI (2013) Water-related ecosystem services and food security. Manag Water Agroecosystems Food Sec 10:29

Copernicus (2019) Corine Land Cover (CLC) 2018, Version 20. https://land.copernicus.eu/pan-european/corineland-cover/clc2018?tab=download. Accessed on $31 \mathrm{Dec} 2019$

De Luca G, Orlotti D (2018) Un Contratto di Fiume per la riqualificazione del Fiume Calore. In: XI ${ }^{\circ}$ Tavolo Nazionale dei Contratti di Fiume e $1^{\circ}$ Congresso Osservatorio Nazionale dei Contratti dei Fiumi, Roma, 5-6 Febbraio 2018, MiniAmbiente, pp. 1-4

Delgado-Aguilar MJ, Konold W, Schmitt CB (2017) Community mapping of ecosystem services in tropical rainforest of Ecuador. Ecol Indic 73:460-471. https://doi.org/10.1016/j.ecolind.2016.10.020

Duku C, Rathjens H, Zwart SJ, Hein L (2015) Towards ecosystem accounting. Hydrol Earth Syst Sci 19(10): $4377-4396$

Egoh B., Reyers B., Rouget M., Richardson D.M., Le Maitre D.C., van Jaarsveld A.S. (2008). Mapping ecosystem services for planning and management. Agric Ecosyst Environ, 127 (1-2):135-140. doi: https://doi.org/10.1016/j.agee.2008.03.013

EU - European Commission (2003). Public Participation in Relation to the Water Framework Directive. Guidance Document, 200

Everard M, Waters R (2013) Ecosystem services assessment: how to do one in practice. Institution of Environmental Sciences, London

Everard M, Colvin JD, Mander M, Dickens C, Chimbuya S (2009) Integrated catchment value systems. J Water Resour Protect 1(3):174

Falkenmark M (2003) Water management and ecosystems: Living with change (Vol. 9). Global water partnership

Farr TG, Rosen PA, Caro E et al (2007) The shuttle radar topography Mission. Rev Geophys 45. https://doi. org/10.1029/2005RG000183

Floridia A (2008) Public deliberation and decision-making processes: the case of Tuscan regional law and citizen partecipation. Stato e Mercato:83-110. https://doi.org/10.1425/26659

Freschi AC, Raffini L (2008) Institutional deliberative process and political framework. The case of Tuscany Stato e Mercato 279-315. https://doi.org/10.1425/27525

Galet-Lalande N (2004) Public debate on the Charlas reservoir project. Int J Hydropower Dams 11(5):108-112

Galloway GE, Seminara G, Blöschl G, García MH, Montanari A, Solari L (2020) Reducing the flood risk of art cities: the case of Florence. J Hydraul Eng 146(5):02520001

Grizzetti B, Lanzanova D, Liquete C, Reynaud A, Cardoso AC (2016) Assessing water ecosystem services for water resource management. Environ Sci Pol 61:194-203

Horlemann L, Jafari BP (2017) Participation in water Management in Iran. In: Mohajeri S, Horlemann L (eds) Reviving the dying Giant. Springer, Cham

Johnson G, Scholes K, Whittington R (2009) Exploring corporate strategy: text \& cases. Pearson education. Galet-Lalande W (2004) public debate on the Charlas reservoir project. Int J Hydropower Dams 11:108-112

Kallis G, Videira N, Antunes P, Pereira ÂG, Spash CL, Coccossis H et al (2006) Participatory methods for water resources planning. Environ Plan C: Gov Policy 24(2):215-234

Kastens B, Newig J (2008) Will participation foster the successful implementation of the WFD? The case of agricultural groundwater protection in north-West Germany. Local Environ 13(1):27-41

Krueger RA, Casey MA (2000) Focus groups: a practical guide for applied research, 3rd edn. Sage Publications, Thousand Oaks, CA

Langemeyer J, Palomo I, Baraibar S, Gómez-Baggethun E (2018) Participatory multi-criteria decision aid: operationalizing an integrated assessment of ecosystem services. Ecosyst Serv 30:49-60. https://oi. org/10.1016/j.ecoser.2018.01.012 
LIFE-REWAT (2019) Contratto di Fiume del fiume Cornia http://www.liferewat.eu/progetto-rewat/contratto-difiume-cornia.html. Accessed on $15 \mathrm{Feb} 2020$

Lindsay J, Rogers BC, Church E, Gunn A, Hammer K, Dean AJ, Fielding K (2019) The role of community champions in long-term sustainable urban water planning. Water 11(3):476

Lopes R, Videira N (2013) Valuing marine and coastal ecosystem services: an integrated participatory framework. Ocean Coast Manag 84:153-162. https://doi.org/10.1016/j.ocecoaman.2013.08.001

Maes J, Liquete C, Teller A, Erhard M, Paracchini ML, Barredo JI et al (2016) An indicator framework for assessing ecosystem services in support of the EU biodiversity strategy to 2020. Ecosystem Serv 17:14-23

MEA (2005a) Millennium ecosystem assessment - ecosystems and human well-being: synthesis. Island, Washington, DC

MEA (2005b). Millennium Ecosystem Assessment and human well-being. Current State and Trends. SeriesEcosystems,

Mendelow, A. (1981). Environmental scanning: the impact of stakeholder concept. Proceedings of the second International conference on information systems. Cambridge, Mass

Morrison K (2003) Stakeholder involvement in water management: necessity or luxury? Water Sci Technol $47(6): 43-51$

Mostert, E., Junier, S., Ridder, D., Interwies, E., Bouleau, G., Bots, P., Maurel, P., Richard, A., Abrami, G., Cernesson, F. and S. Richard (2009): Research Report No 1. Innovative Instruments and Institutions in Implementing the Water Framework Directive: i-five inception report. [www.i-five.org]

Nyumba T, Wilson K, Derrick CJ, Mukherjee N (2018) The use of focus group discussion methodology: insights from two decades of application in conservation. Methods Ecol Evol 9(1):20-32

Olsson P, Folke C, Galaz V, Hahn T, Schultz L (2007) Enhancing the fit through adaptive co-management: creating and maintaining bridging functions for matching scales in the Kristianstads Vattenrike biosphere reserve, Sweden. Ecol Soc 12(1)

Pahl-Wostl C, Jeffrey P, Isendahl N, Brugnach M (2011) Maturing the new water management paradigm: progressing from aspiration to practice. Water Resour Manag 25(3):837-856

Palomo I, Martín-López B, López-Santiago C, Montes C (2011) Participatory scenario planning for protected areas management under the ecosystem services framework. Ecol Soc 16(1):23

Paudyal K, Baral H, Burkhard B et al (2015) Participatory assessment and mapping of ecosystem services in a data-poor region: case study of community-managed forests in Central Nepal. Ecosyst Serv 13:81-92. https://doi.org/10.1016/j.ecoser.2015.01.007

Razzaque J (2009) Public participation in water governance. In: The evolution of the law and politics of water. Springer, Dordrecht, pp 353-371

Regione Toscana (2013a). Law 46/2013. Dibattito pubblico regionale e promozione della partecipazione alla elaborazione delle politiche regionali e locali

Regione Toscana (2013b). Strategia regionale per la biodiversità. Piano Ambientale ed Energetico Regionale (PAER) 2013-2015

Regione Toscana (2018a). Progetto "WaterValues- Il valore dell'acqua" - Libretto del partecipante http://open. toscana.it/documents/738709/0/Libretto+del+partecipante

Regione Toscana (2018b). Report focus groups (in Italian). Available at : http://open.toscana.it/web/watervaluesil-valore-dell-acqua/documenti

Regione Toscana (2018c). Patto costitutivo del Contratto di Fiume del torrente Pesa http://open.toscana. it/documents/560649/0/Patto+Costitutivo+del+Contratto+di+Fiume+del+Torrente+Pesa/6dc71a2a-04a54146-81a8-1534e34a34b9. Accessed on 15 Feb 2020

Regione Toscana (2019). Land use dataset "Uso e copertura del suolo 2007-2016". http://www502.regione. toscana.it/geoscopio/download/tematici/ucs_rt/. Accessed on 31 Dec 2019

Ridder D, Pahl-Wostl C (2005) Participatory integrated assessment in local level planning. Reg Environ Chang 5(4):188-196

Ruiz-Villaverde A, García-Rubio MA (2017) Public participation in European water management: from theory to practice. Water Resour Manag 31:2479-2495. https://doi.org/10.1007/s11269-016-1355-1

Schröter M, Remme RP (2016) Spatial prioritisation for conserving ecosystem services: comparing hotspots with heuristic optimisation. Landsc Ecol 31(2):431-450

Spangenberg JH, von Haaren C, Settele J (2014) The ecosystem service cascade: further developing the metaphor. Integrating societal processes to accommodate social processes and planning, and the case of bioenergy. Ecol Econ 104:22-32

Steger C, Hirsch S, Evers C, Branoff B, Petrova M, Nielsen-Pincus M, Wardropper C, van Riper CJ (2018) Ecosystem services as boundary objects for transdisciplinary collaboration. Ecol Econ 143:153-160. https://doi.org/10.1016/j.ecolecon.2017.07.016 
Stocker L, Burke G, Kennedy D, Wood D (2012) Sustainability and climate adaptation: using Google earth to engage stakeholders. Ecol Econ 80:15-24. https://doi.org/10.1016/j.ecolecon.2012.04.024

Stosch KC, Quilliam RS, Bunnefeld N, Oliver DM (2017) Managing multiple catchment demands for sustainable water use and ecosystem service provision. Water 9(9):677

TEEB (2010). The economics of ecosystems and biodiversity: Ecological and Economic Foundation Earthscan, London and Washington

Van Ast JA, Gerrits L (2016) Public participation, experts and expert knowledge in water management in the Netherlands. Water Policy 19:115-127. https://doi.org/10.2166/wp.2016.253

Voghera, A. (2015). River contracts in Italy. An experience for river management. In Proceedings of the Conference Energy, Environment, Development and Economics (pp. 351-362)

WFD (2000). Water Framework Directive 2000/60/CE

Wunder S, Wertz-Kanounnikoff S (2009) Payments for ecosystem services: a new way of conserving biodiversity in forests. J Sustain For 28(3-5):576-596

Publisher's Note Springer Nature remains neutral with regard to jurisdictional claims in published maps and institutional affiliations.

\section{Affiliations}

\section{T. Pacetti ${ }^{1} \cdot$ G. Castelli ${ }^{2} \cdot$ E. Bresci ${ }^{2} \cdot$ E. Caporali ${ }^{1}$}

1 Department of Civil and Environmental Engineering (DICEA), Università degli Studi di Firenze, Via di S. Marta, 3, 50139 Firenze, Italy

2 Department of Agriculture, Food, Environment and Forestry (DAGRI), Università degli Studi di Firenze, Via San Bonaventura, 13, 50145 Firenze, Italy 